\title{
PROSPECTS
}

\section{A sequence for success}

\section{The next generation of DNA sequencers could create more genomics jobs, says Paul Smaglik.}

\author{
Bioengineer Stephen Quake and his colleagues \\ at Stanford University, California, reported \\ earlier this month that they had sequenced \\ Quake's own genome in 4 weeks for less \\ than US $\$ 50,000$, leading to predictions that \\ physicians will soon be able to sequence \\ patients' DNA in their offices (D. Pushkarev, \\ N. Neff and S. Quake Nature Biotechnol. \\ doi:10.1038/nbt.1561; 2009). Yet such \\ predictions may be premature - the machine \\ used by Quake costs around $\$ 1$ million, and \\ sequencing one patient's genome currently \\ yields little clinical benefit. Still, the next- \\ generation sequencing technology the group \\ reports could boost careers in three areas of \\ genetics and genomics. \\ First, it is likely to prompt the development \\ of even cheaper, better and faster sequencing \\ technologies. Companies such as Helicos \\ Biosciences in Cambridge, Massachusetts, \\ which developed the sequencing technology \\ used by Quake, and others will race to generate \\ improved instruments. That should mean jobs \\ for biomedical engineers and computational \\ biologists who can develop and test new \\ sequencers and bioinformatics approaches. \\ Second, this technology can be used \\ with bioinformatics to unearth the complex \\ multiple-gene variants that drive many \\ diseases, such as cancer, and will enable \\ cheaper and faster genomic sequencing \\ of individuals with the same disorders. \\ Bioinformaticians and biostatisticians will \\ be needed to compare genomes directly to
}

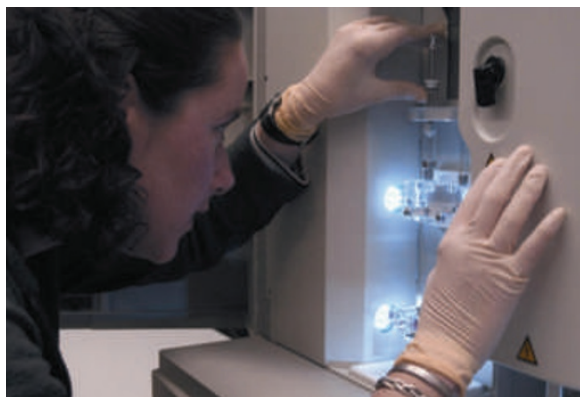

Rapid-sequencing technologies are getting a boost.

reveal the multiple genes or variants that cause a particular disease.

Third, an improved understanding of these variants should help move drug development into the era of personalized medicine, requiring pharmacogeneticists who can tailor drug therapies to individuals that have different genetic variants.

Another stimulus for genomics jobs comes from funding. The US economic recovery act is already channelling money into two Department of Energy labs to purchase faster sequencing equipment and to develop better bioinformatics software. And with Francis Collins confirmed as the new director of the National Institutes of Health, the former leader of the Human Genome Project is in a strong position to advocate funding of the latest rapid-sequencing technologies.

Paul Smaglik is a freelance writer based in Milwaukee, Wisconsin.

\section{POSTDOC JOURNAL}

\section{A strong idea}

Last weekend was fun. I didn't get to bed before midnight either night. Sometimes work is like that.

On Friday afternoon, while

fine-tuning a paper about a model of intramolecular interactions in myosin, a protein integral to muscle contraction, I found a paper about an experiment with a related protein.

At first, I was excited to find that my model predicted the experimental results. But my excitement evaporated when I read the authors' simple, logical and elegant explanation - an explanation that completely contradicted my results. I felt sick thinking about what seemed to be wasted effort.

I thought about another time when my work had disintegrated at the final moment. Several years ago, while finishing a manuscript, I found a paper that had been published 30 years earlier. This paper presented 'my' idea and explained it 'my' way. I had felt a mix of emotions. Although it was nice to know l'd been right, I had nothing to show for it.

But on Friday evening, after a few hours of frantic thinking, I hit on an idea that explained why my model was correct. As the weekend passed, my excitement mounted and the idea gained clarity. I went to bed late Sunday night, calm and happy. The paper had survived the moment of doubt and had emerged stronger. Weekends like this make me glad to be a scientist. In science, sometimes you work hard and fail, but sometimes you work hard and succeed. The failures are what make success so sweet. Sam Walcott is a postdoc in theoretical biophysics at Johns Hopkins University in Baltimore, Maryland.
IN BRIEF

\section{UK grants in refund threat}

A inflation rate lower than that predicted may force some UK research scientists to refund research allocations. The UK government has asked the nation's seven research councils, which distribute government research funding, to come up with about $£ 100$ million (US\$165 million) in cuts.

The government had forecast an annual inflation rate of $2.7 \%$, and had based its funding levels on that figure, but the actual rate has averaged $1.5 \%$. The councils say that they are deciding how to come up with the funds they must repay the government. Asking researchers to return allocations could help them to reach their goal but could also alienate scientists.

\section{College salaries put on ice}

Two-thirds of independent US colleges and universities polled in a recent survey said they plan to freeze employee salaries. Of those respondents, $80 \%$ said the freeze would be imposed across the institution; $15 \%$ said it would affect only the president and top executives; and $6 \%$ said only the president's salary would be capped.

Yet $24 \%$ of all respondents said they plan compensation increases, with $87 \%$ of that group expecting to raise salaries across the board. Nine per cent of respondents predicted they would make pay cuts, with $64 \%$ of those saying the reduction would be institution-wide. The survey, conducted in June by consultants Yaffe \& Company of Towson, Maryland, produced responses from 259 institutions in 39 states.

\section{A guide for policy work}

Those considering a career in public policy now have a new edition of an existing resource to help guide their path. The American Association for the Advancement of Science (AAAS) has updated and expanded its 1985 Guide to Graduate Education in Science, Engineering and Public Policy.

The fourth edition of the guide is now available for free online at www. aaas.org/spp/sepp. Albert Teich, the AAAS's director of science and policy programmes, says that science and technology have taken on more important roles in public policy since the guide was first published. "The need for people educated in this field has grown proportionately," Teich says. 